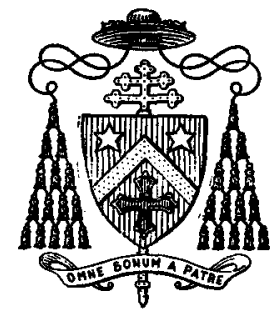

\title{
The Importance of the Role of History and Classical Studies in the Moulding of Man
}

\author{
HIS EMINENCE GABRIEL-MARIE CARDINAL GARRONE
}

In these brief reflections on the role of History and Classical Studies in the shaping of man I should like to pay homage to the work of your Committee, in which History and, in particular, Geography, employing diverse other sciences, endeavour to give to mankind in an unbiased manner the possession and knowledge of a considerable and largely unknown section of his past and of his present terrestrial domain.

Who does not recognize, behind your intentions in the task you have set yourselves, a fundamental interest in man himself? In helping him to discover his deeds over the course of the centuries, his possibilities, in leading him to know a little better this earth with which his future is inextricably bound up, you assuredly intend to serve his interests. Is it not one of the noblest and profoundest ambitions of anyone who has given life to a son and enveloped him with love, to wish to pass on to him all that he has been able to acquire himself, including the fruits of all the labours and experience he has built on to his own inheritance and above all enduring spiritual riches, which are impervious to envy and aloof from hate?

And so History thrusts itself upon us as part of our formation in the sense that it is a continuous process, manifested, accepted, and lived. He who lives only "for the moment" betrays the condition of man and sinks down the scale of being. He who wishes to mould his life must be made aware of what he owes to the past and what it can offer him, bearing in mind the image of the ancients that each generation is like a dwarf perched on the shoulders of a giant.

It is therefore with a sort of anguished stupor that one sees the teaching of History disappear from teaching programs in so many countries and the classical humanities pushed into the background by the amazing advance of the sciences, amidst general indifference and apathy. The future of History and of the humanities are closely linked in this general spurning, which is why I wanted to draw your attention to this for a few moments, for to be unaware of History and to depreciate literary culture is to be ignorant of man and to abandon hope of his improvement.

While it is true that History is under constant attack it is also true that it regularly recovers, but not without wounds and imbalances, always difficult and sometimes impossible to repair. The lacunas are filled from time to time, opening up new lines of enquiry in fields in which all further research had been considered exhausted, but at the same time as these gaps are filled others are engendered. Even among men considered cultured it is easy to find some who know absolutely nothing about entire centuries of human History. The long thread of History is broken in many places. An investigation into this improbable, one could almost say abysmal, ignorance among the great majority of people would produce some strange surprises. It is a situation which is bound to have unfortunate consequences: a fatal recourse to ready-made opinions, a total dependence on those who are thought to or think that they possess knowledge, an absence of curiosity, a lack of reference points from which to judge the present and, finally, the shameful and desperate belief in Nostradamus...! But, as I have said, there is no shortage of excuses to encourage this lack of culture; witness the sarcasm Valéry heaped on History...and the objections should be taken seriously. History, it is said, is a peculiar educator if one considers the accumulation of horrors and crimes... and one can ask on what certitudes is the teaching of History based at a time when the sciences show proof of much greater efficacy. Neither of these arguments can really be accepted.

If one accepts that man is capable of evil one also has to accept that he is capable of good. The dreadful crimes of the past and present should be contrasted with the wholly admirable and marvellous feats and creations revealed by genius, saintliness, and ordinary humble humanity. The past is strewn with works which have outlived the centuries and withstood the weathering of time and human forgetfulness. What men of intelligence and love have done to benefit mankind is paid slight attention: a Francis of Assisi has produced more durable and impressive work than a Stalin. If History reveals his weaknesses to man it also shows his greatness. It falls to teachers to point out not only to what depths man can sink but also to what heights he can aspire. 
As for the second argument - if History appears to be a minor science in conjunction with the exact sciences it is only because its completely unique character is misunderstood. It is not the mission of History to discover new laws and thereby to create useful techniques. Its raison d'être is completely original. In a sense History will always remain more real than the sciences where the subject and result are abstract. History provides the point through which all general knowledge is inserted into reality, for the real is always individual. History unites the real in the encounter with man who has the freedom to use his techniques and direct them to an unforseeable end.

This is why History is always disconcerting. It records but does not lend itself to permanent satisfactory results, for it includes man with his initiatives and contradictions. History is not a theorem for, as Pascal says, man is not a theorem. Yet History engenders a "wisdom" which is not easy to put into a formula but which shows man his limits and his capabilities. It begets a moderation which the ancients expressed in the word "Nemesis", which guards against false adventures but gives at the same time a zest for risk. It is for educators to realize how best to use such an instrument; they should know that it is something they cannot be without and if it happens that they care about the condition of man, History will be to them the most important instrument of all.

I have mentioned in the same breath as History classical culture, which tradition significantly labels the "Humanities". Whatever the defects, blunders, inadequacies, and errors that have often nullified the advantages to be gained from this means of formation, it is still nevertheless indispensable. I should now like to take up this question, though it must be admitted that there are many good arguments which make this a difficult cause to defend.

It has to be acknowledged that the teacher is not always equal to the task in this field. One commonly hears those who have had the advantage of an initiation into the humanities complain about the pure waste of precious years: the few traces which swim to the surface of their memories - a verse of Virgil, or of Corneille - seem like dead wood to them, ridiculous apologies in proportion to the unpardonable abuse of their defenceless youth. I am not sure - unless they had very bad teachers - that these years have left nothing in the depths of their spirits or memories, for they do not always recognize the unsuspected benefits left by these disciplines which give them, compared with others less fortunate, an ease in their way of thinking and expression, a clarity in explanation, and, finally, an intellectual exigency for which they are indebted to their training. But it must sadly be admitted in pleading for the Humanities that often they have not been or are not what they should have been or should be.

An unfortunate experience due to unskillful teaching does not alter the fact that the Humanities are a normal channel for the moulding of man's character and a way of accepting fundamental values difficult to acquire otherwise. To form a man is to help him discover his inner self; once this path is open he is ready to go out and meet others. If one fails to open up this double discovery one could say that one has failed in one's task.

So, the first duty is to help man understand himself - a difficult task when master and pupil hide from each other in turn. Today more than ever man is taken out of himself. Daily he is rendered prisoner by images offered on approval, and carried along on a tide of activities at a furious pace. The only way he knows of escaping this bondage is to ask the same purveyors for other images and other activities. In the end he tries to escape from himself without realizing it. It has never been more difficult for a man to stay peacefully in a room on his own. To be able to do this he needs to be familiar with the experience of other men to have had patient and continued contact with the enduring witness to posterity of the lives and writings of men from past centuries. There lies the inheritance preserved and communicated by classical literature. The texts that have survived the vicissitudes of History help man to understand himself by contact with those who have been able and knowledgeable enough to do this earlier. Time respects what is good and true and effaces the rest. Thus, face-to-face with himself man begins a dialogue with himself which is the essential basis for a dialogue with others, but which first reveals to him his own personal existence and the possibility of communing with his inner spirit and being. Before sharing in the conception of men as to what man is, we must first discover the History of man by seeing ourselves reflected in the mirror offered to us. Such a privilege is not always recognized and we are not always conscious of our debt. In "rubbing up against others", as Montaigne, who understood this so well, rightly said, the need and possibility becomes clear for an innate, interior conversation. One has learned to "reflect" literally, for to look in the mirror offered by another is to make an acquaintance of oneself. 
This is not the place to go further into this aspect of what is accomplished by an. association with the "classics" with all the study called for and the skills which develop from it - think, for example, of the effort required to translate into one's own. language what another has said in his. It only remains to add that if man wishes to surpass himself and aspire to the heights; the only way to do this is through his inner being: as Saint Augustine has expressed so admirably, "from without to within, from within to the sublime". Let us now leave this question to consider another simpler and more immediate matter.

Are we sufficiently aware that real communication with others begins from our inner being? How is it conceivable to hold a real dialogue unless one believes in one's own existence? Bernanos rightly wrote, "where does the idea come from that solitude drives men away and prevents one from understanding them? It is only in silence and solitude that one finds oneself, the verity of oneself, and it is only through this verity that one can comprehend that of others." It is by looking itwards that one becomes fit to communicate and hold a real dialogue with another. In discovering others one discovers oneself and becomes able to listen to others. It is true that written documents and literary.texts are not the only means of communication, but they remain the most precious if one reflects on those which the passage of time has respected, in which man exposed himself in his entirety. How can one measure the benefits of prolonged and habitual intercourse with the thoughts of Pascal, the works of Shakespeare, of Goethe and Dostoyevsky, not to mention Plato? Our conversation with the dead; these distant witnesses to our humanity, whose opinions have withstood the test of time, is a true conversation with man. It is a preparation for the time when the opportunity occurs to profit from the daily exchanges with companions along the road today.

You could say that these ideas are inspired by a narrow classical outlook: that the world today holds other geographical and historical dimensions, that there is now access to other cultures comparable in value to the Greek and Roman civilizations. No one can deny this. But for us the approach to these other cultures and civilizations is through the exploitation of the resources springing from our own roots. In becoming more conscious of the wonderful riches within the framework of our own horizons we are in a better position to avoid misunderstanding cultures coming. from another sphere. I would imagine that the travels necessitated by your original researches into remote areas have nat suffered or been prejudiced by a contact with the "classicists".

I must conclude by admitting that this whole question hangs suspended on the quality of the teaching, and that the classics can be badly served. The important thing is to keep the essential values within view: man's discovery of his inner self, thence the real discovery of others. The more we bear these values in mind and the more we come to understand the significance of history and of the classical disciplines, so much the more may we hope for their progress and enrichment through the extraordinary contributions of these times in which you yourselves are so actively engaged.

I cannot do better than to conclude by quoting the awe-inspired words of the old Greek philosopher, "What a wonderful thing is man, on condition that he be truly man". This is certainly the inspiration of your work. I am sure that this Congress will give you a greater certitude of this truth and perhaps the ability to communicate it to others. For myself, I thank you.

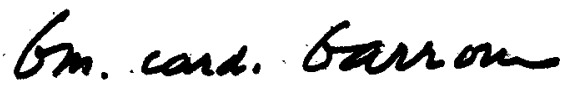

